\title{
Archives, Performance, and Resistance in Uruguayan Art Under Dictatorship
}

Between October And November of 1983, the installation Sal-si-puedes (Exit if you can) by artist Nelbia Romero, was shown at the Galería del Notariado in Montevideo. At one point in the pathway through the gallery space, broken mannequins lay splattered in red paint (fig. 1). This image visually replicated what everyday reality condensed into a complex amalgam of experiences that had slowly been accumulating from the time of the coup d'état on June 27, 1973, and throughout the years of the Uruguayan civil-military dictatorship from then until 1985. This coup was no spectacular, sudden, and violent experience like the one a few months later in Chile, with the bombing of the Moneda Palace, soccer stadiums filled with prisoners, and the detentions and urban murders. In the Uruguayan case it was a pact or form of defection of the democratic powers that resulted in the establishment of a military system whose repressive forms were consolidated through the prison system, torture, death, disappearances, censorship, and exile; mechanisms that gradually accumulated and increased. ${ }^{1}$

Romero's Sal-si-puedes made reference to Salsipuedes, the historical name of the encounter that took place in 1831 between the then recently established military forces of the Oriental Republic of Uruguay and the indigenous groups of the area. The name Sal-si-puedes does the work of literalizing the idea of entrapment and confinement that resulted in the massacre that in turn consolidated the extermination of indigenous people in Uruguay. Romero's installation consisted of a series of expressions in several different media. Various objects were organized in a walkthrough; a musical score was composed especially for the piece; photographs of a dance performance about the different episodes of the violent encounter were used as the basis for a projection of slides inside the installation; and a small folder of quotes

A B S T R A C T This essay analyzes the 1983 installation Sal-si-puedes by Uruguayan artist Nelbia Romero, and its status as an act of resistance, in light of the dictatorship then in power in her country. Representations 136. Fall 2016 (C) The Regents of the University of California. ISSN 0734-6018, electronic ISSN 1533-855X, pages 36-53. All rights reserved. Direct requests for permission to photocopy or reproduce article content to the University of California Press at http://www.ucpress.edu/journals. php?p=reprints. DOI: 10.1525/rep.2016.136.3.36. 


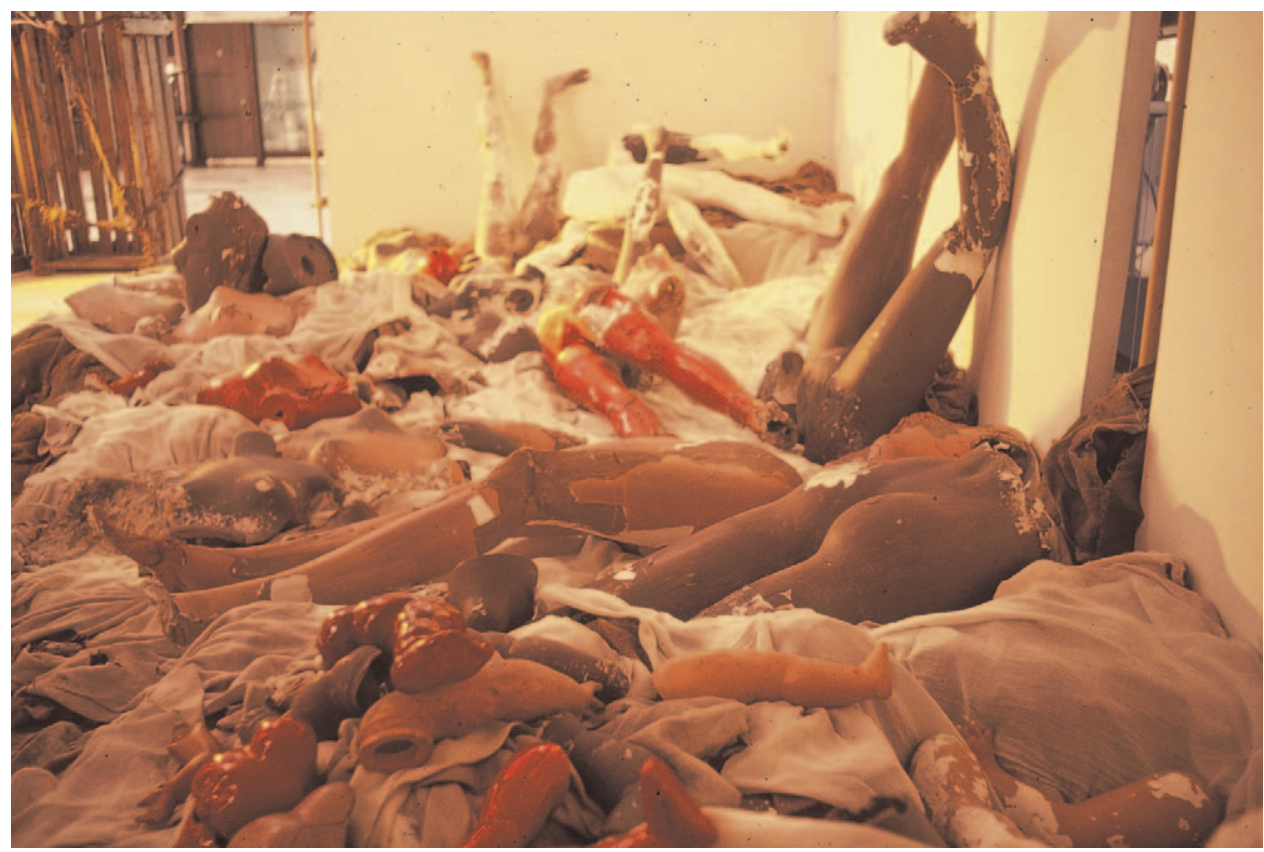

FIGURE 1. Nelbia Romero, Sal-si-puedes, 1983. Installation at Notariado Gallery (section of mannequins), Montevideo. Photo: Diana Mines.

from historical documents was made available to installation viewers. Along with its complex materiality, which required the spectator to reconstruct meaning from a diversity of sonic, visual, and written archives, as well as from an experience of her own body, the theme of the installation-as well as the moment in which it was created-is relevant. Sal-si-puedes took up a violent episode that was constitutive of the state's formation, actualized under the conditions of censorship and violence imposed by the dictatorship.

The installation combined a series of social, political, and aesthetic plots. On the one hand, it proposed a reading of a past massacre in a contemporary repressive context. On the other hand, it aimed to stage the subjectivities conditioned by the climate of censorship through a complex, interdisciplinary web. The reception and interpretation of the piece must therefore be understood in the repressive context of the dictatorship. Testimonies from Romero's contemporaries evidence a use of opaque and complicit codes, means of expression that remain inconspicuous to the castrating gaze of the dictatorship and allow us to imagine microsocieties of meaning and dialogue from which reading communities were formed. I think of these collectives as part of the intellectual and artistic networks that sought to articulate dissident messages and activities in relation to repressive 
state control during the years of the dictatorship. In addition to these networks and messages, in this essay, I'm also interested in addressing the historicist effect of Romero's installation, into which archival documents were incorporated as a way of bringing unresolved aspects of the past into the present. In no way, of course, do I intend to resolve them, but I aim, precisely, to point out their latency and unrest. Taken together, the disparate parts of Sal-si-puedes is a package of experiences that appeals at the same time to the body and to the different senses with which the documents of the past are interwoven in contemporary thought and experience.

\section{Archives}

According to a map of Romero's installation (fig. 2), one entered Sal-si-puedes through a large tent constructed out of bags that had been used to transport wool from the port of Montevideo. ${ }^{2}$ The tent's exterior was stained with red and white paint, and the inside was covered with white fabric (fig. 3). At the end of the walkthrough, the tens of broken, discarded mannequins of female bodies composed a brutal image, albeit artificial and parodic, that distanced the spectator and precluded empathy. The walkthrough culminated in four monumental crates crossed by thick ropes. ${ }^{3}$

In addition to this archive on the material construction of the installation, another brings together black and white photographs of three women, among them Nelbia Romero, who produce gestures of pain, struggle, and agony (fig. 4). The photographs, which captured a prior studio performance, were projected inside the tent. ${ }^{4}$ They were arranged in four episodes corresponding to the encounter between the forces of President Fructuoso Rivera (1784-1854) and the native people of the region in 1831. In addition to the photographs, an accompanying musical score composed by Fernando Condon and Carlos da Silveira, organized in the same four-part structure, has also been preserved. ${ }^{5}$

Accompanying this display of materials was a manila folder in which, along with the credits for the piece and a text providing historical reflections, some nineteenth-century documents were included. The historical reflections referred to the essential aspects of the extermination of the Charrúa people in Uruguay. ${ }^{6}$ They recall the origins of a country that represents itself as devoid of indigenous peoples, in order to remind us that such a myth is founded on a massacre carried out by the first democratically elected president. They recall that the same Chaná-Charrúa people who had acted as personal guards to General Jose G. Artigas, would become an annoying presence a few years after Artigas's defeat for those who coordinated the interests of the nascent nation (holders of property deeds who 


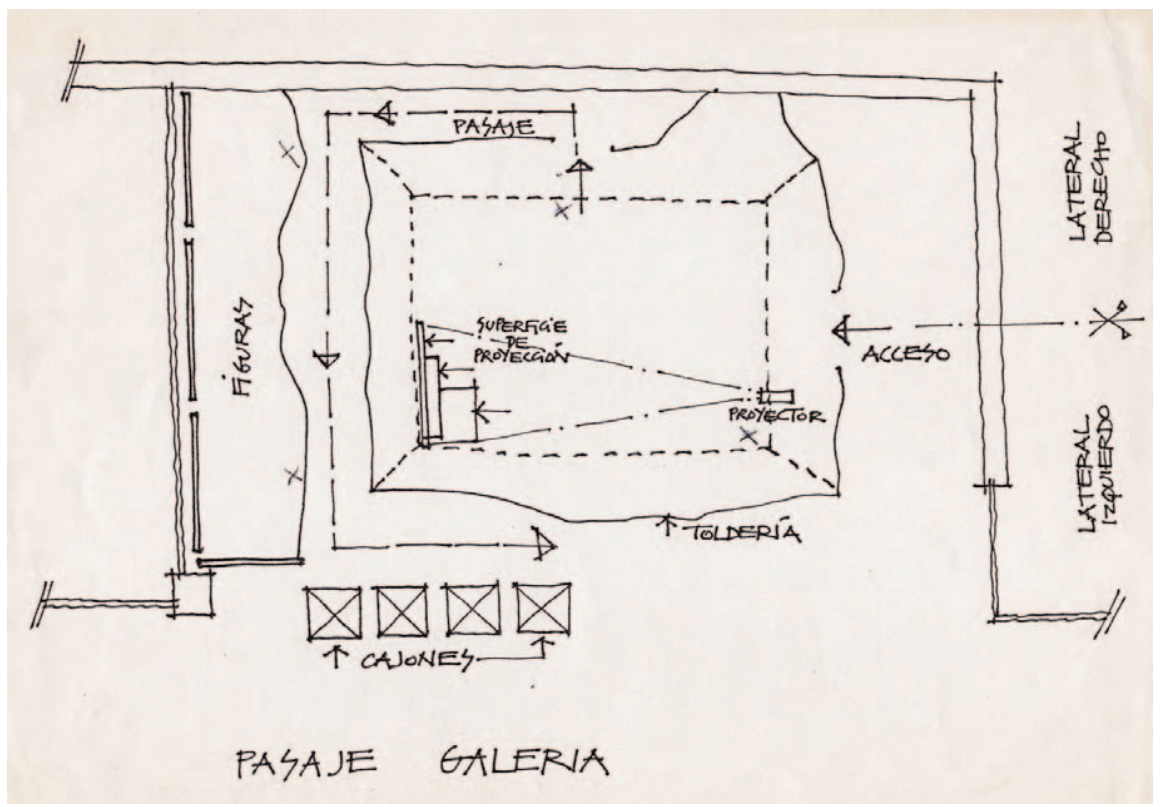

FIGURE 2. Romero, Sal-si-puedes. Map of the installation at Notariado Gallery, Montevideo.

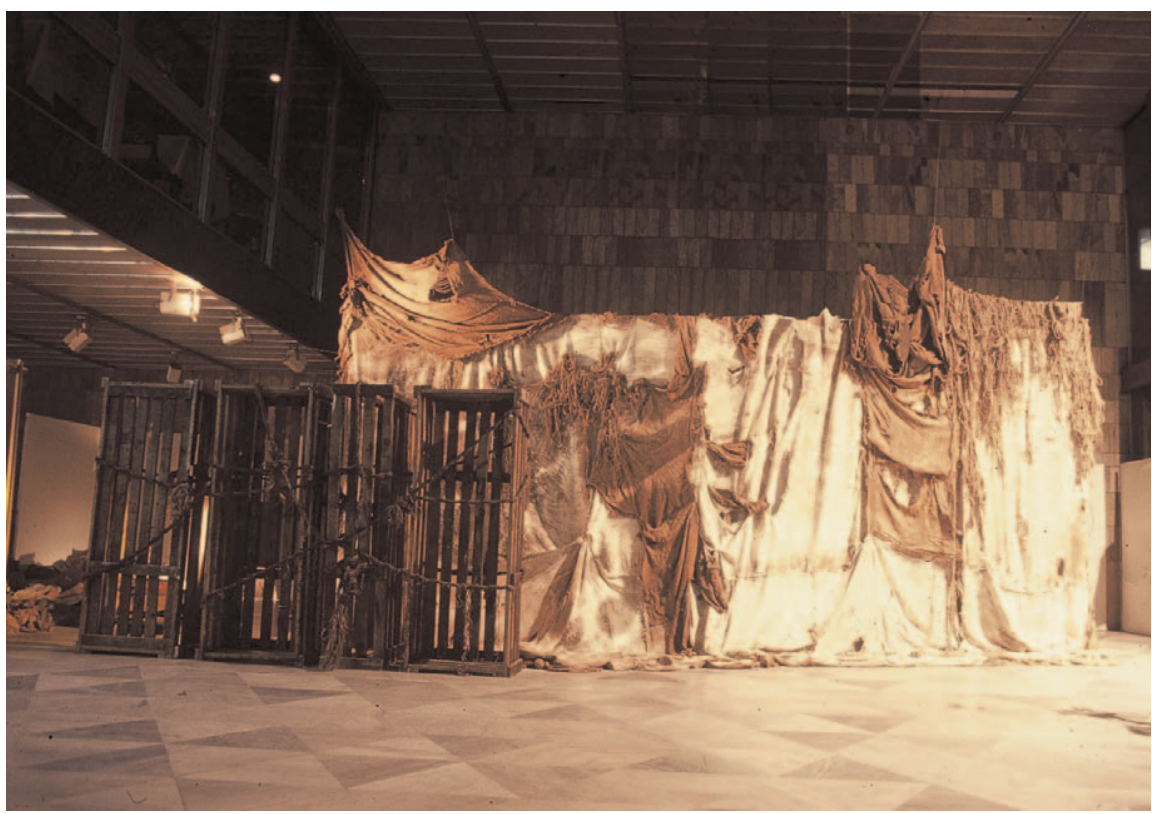

FIgure 3. Romero, Sal-si-puedes. Installation view. Photo: Diana Mines. 


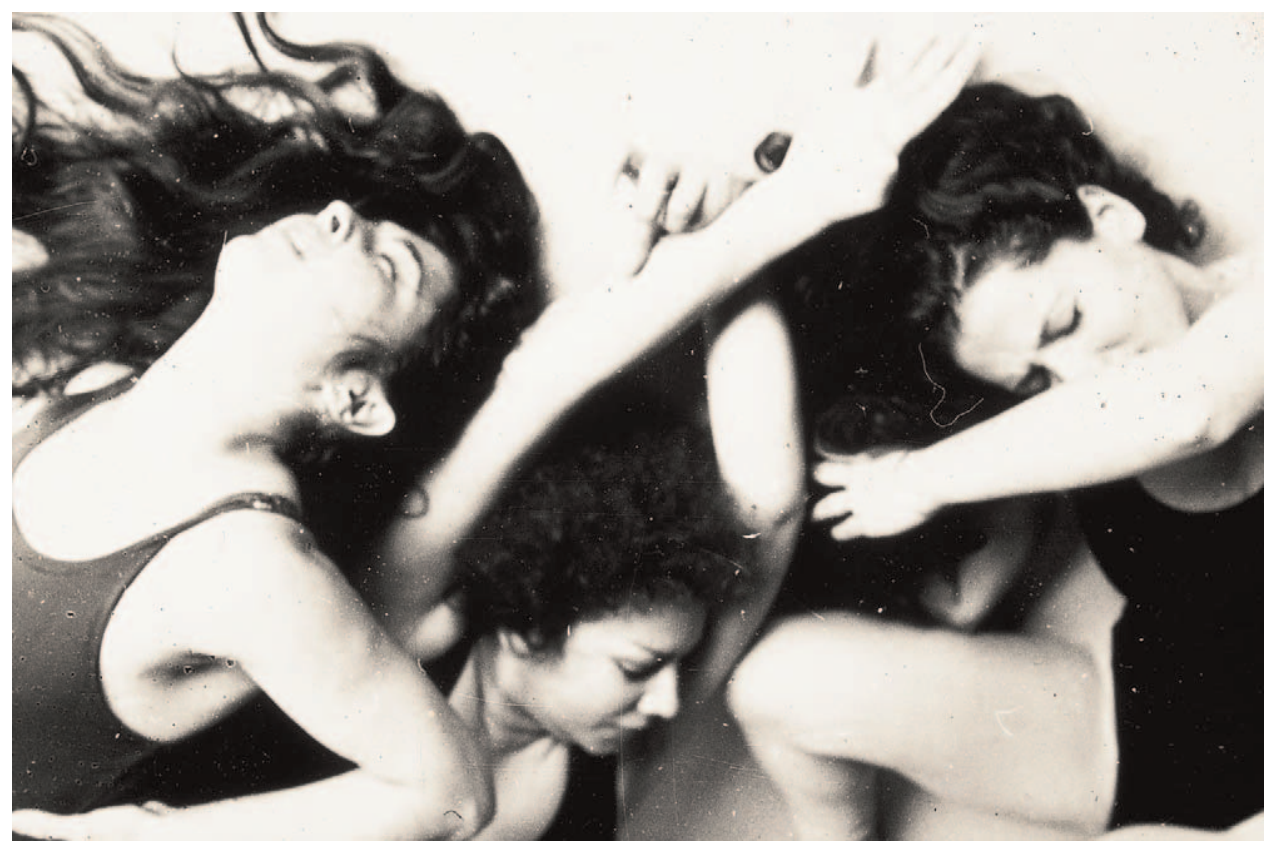

FIGURE 4. Carlos Etchegoyen, performance photograph projected inside Romero, Sal-si-puedes.

wanted them evacuated; ranchers who accused them of stealing livestock; the European intelligentsia, with their attitude of colonial entitlement). The militant revolutionary Juan Antonio Lavalleja had advised Fructuoso Rivera to adopt security measures in favor of property owners against the Charrúas, who were considered "malvados que no conocen freno alguno que los contenga" (evil men who know no brake to restrain them) and who, he argued, could not be "librados a sus inclinaciones naturales" (left to their natural inclinations). ${ }^{7}$

The extermination of the native people was set in motion by Rivera, who in the spring of 1831 summoned the principal Charrúa chiefs (Venado, Polidoro, Rondeau, and Juan Pedro), together with their wives and children, under the pretext of engaging them to protect the state's borders. Several hundred Charrúa showed up and were invited to drink. Rivera then killed the chief Venado with a single shot, and this was the signal to begin the slaughter of Puntas del Queguay on 10 or 11 April 1831. According to official Uruguayan history, forty Charrúas were killed and three hundred were apprehended. Some managed to get away. Those who survived, primarily children, women, and the elderly, were distributed through raffles or were given away to foreigners. Four of them (Vaimaca Perú, Tacuabé, 
Senaqué, and Guyunusa) were given to the Frenchman François de Curel, who in 1833 took them to Paris, where they were exhibited and studied as exotic specimens. It is said that Guyunusa was pregnant when she was taken to Europe. The same year that she arrived in Paris she gave birth to a girl, Micaela Guyunusa, assisted in the birth by her companion, Tacuabé (or Vacuavé, as he is called in French sources). They all died between 1833 and 1834, except Tacuabé, who escaped along with Guyunusa's daughter, who in turn died a year later. It is not known when Tacuabé died. Today there are busts of Vaimaca Perú, Senaqué, and Guyunusa at the French embassy in Montevideo. Vaimaca Perú's skeleton, preserved at the Natural Science Museum in Paris, was repatriated to Uruguay in $2002 .{ }^{8}$ An article signed with the initials "L. P." in the newspaper Le National, described chief Vaimaca Perú:

[Vaimaca Perú] habla con bastante soltura el español y entiende también el portugués.... Deseó, por ejemplo, ver al rey de los Franceses. Es el único hombre que su orgullo de príncipe no juzga indigno de ser visto por él en tierra extranjera. Se propone pedirle una nave y unos cien hombres para volver a América, cortarle la cabeza al presidente Ribéra, y vengar a su nación.

[\{Vaimaca Perú\} speaks Spanish with considerable fluency, and also understands Portuguese.... He wished, for example, to meet the French king. He \{the king\} is the only man who his prince's pride doesn't consider unworthy of his visit in a foreign land. He plans to ask for a ship and a hundred men in order to return to America, behead president Ribéra, and revenge his nation.] ${ }^{9}$

The chief had not forgotten the massacre of his people. He expected, when claiming his revenge, to have the support of an equal, the king of France.

The particular tragedy of Guyunusa, a woman who was captured and sent to Paris pregnant, has an additional political and symbolic resonance that persists in contemporary Uruguayan feminist groups, for example in the nonprofit organization "Accionar entre mujeres-Guyunusa" (To activate amongst women-Guyunusa) in present-day Maldonado City.

The story also establishes a relationship between the myth of a white country (without native people) and the massacre. That mass killing, as well as the importance of the Charrúas to Uruguayan culture, has been consistently downplayed in liberal perspectives that present the extermination of the indigenous people as a confirmation of "national values" or even "civilization." A few years ago, ex-president Julio María Sanguinetti stated in an article published in the newspaper El Pais:

No hemos heredado de ese pueblo primitivo ni una palabra de su precario idioma..., ni aun un recuerdo benévolo de nuestros mayores, españoles, criollos, jesuitas o militares, que invariablemente los describieron como sus enemigos, en un choque que duró más de dos siglos y los enfrentó a la sociedad hispanocriolla que 
sacrificadamente intentaba asentar familias y modos de producción, para incorporarse a la civilización occidental a la que pertenecemos.

[We have not inherited from that primitive nation a single word of their scarce language ..., nor a benevolent memory from our elders, Spanish, criollos, Jesuits or military, who invariably describe them as their enemies in a hard collision that lasted over two centuries, and that pitted them against the Hispanic-criolla society that, through much sacrifice, attempted to settle down families and modes of production in order to incorporate themselves to the Western civilization that we belong to. $]^{10}$

To revisionist historiography, Salsipuedes represents the first of a series of campaigns aimed at persecuting and exterminating the Charrúa people, undertaken as part of the constitution of the Uruguayan state. Historian Gonzalo Abella considers those Charrúa children who were given away as pets to the rich families of Montevideo, and whose identities were erased, to be the first of the disappeared, and that the Salsipuedes ambush can be considered the first terrorist act at the hands of the state. ${ }^{11}$

The quotations from documents that were printed in the manila paper booklet came originally from historical archives uncovered by Eduardo Acosta y Lara and published in installments between 1969 and 1970. Written in old Spanish during the first half of the nineteenth century, these archives are a testament to the violent acts to which Romero's installation referred and proof that the documents' author tried to present the massacre as a normative act in the foundation of a civilized nation. By citing these documents, Romero's installation endorsed the historicist impulse common to many more recent artistic expressions. ${ }^{12}$ In such expressions, the variously sourced materials refer to the historical moment upon which contemporary revision is grounded. The archive actualizes the past in the present.

\section{Bodies}

If we observe the installation's map carefully, it is possible to identify the different areas of a labyrinthine walkthrough that includes zones of projection and of transition, spaces in which the mannequins (referred to as "figures") were displayed, and the crates. The four crosses indicated on the map show the location of the tape players from which music was broadcast. ${ }^{13}$ The photographs projected inside the tent were from a performance by Romero and the dance group Babinka. This performance was part of a web of artworks that crossed languages; cultural formations of the second half of the 1960s (particularly those by women) that took the body as their subject. The emergence of performance art and the concurrent trend in dance away from classical forms and patterns, established 
a zone of contact between the body and the visual arts via the introduction of objects as part of a ludic exploration (as can be seen in the work of Uruguayan dancer Teresa Trujillo or that of Argentinian dancers Ana Kamien, Graciela Martínez, or Marilú Marini). In these encounters among the arts, zones of exchange were created between genres that had previously been expressed in separate fields. Romero similarly used the language of the body to stage the moments of the Charrúa massacre. It is important to note that the confrontation of the massacre, which sources describe as having been between soldiers and native people, was here played out by women. This is relevant because it confirms the importance of the body in the artistic expression of women since the 1960s that is present in many other expression of Latin American art.

The projected images organized the performance into four moments: "beginning," where the encounter between the Charrúas, Rivera's soldiers, and the landowners of the region takes place; "rite," which represents the moment when the intoxicated Charrúas are locked up in the ranch and the first shot is heard; "destruction," which alludes to the battle between natives and soldiers; and "death," which refers to the deaths of the Charrúas and which, during the performance, is signaled by the photographs of bodies that lie on the floor, as well as the mannequins and crates.

The artist's corporeal presence in her own work is linked to a wider understanding of the body during those years that involved its inscription in political and artistic action. Gabriel Peluffo Linari traces a significant relationship between the body and politics and art starting with the concept of "placing the body," a phrase that in Uruguay is connected to both the political stage of protest and repression and the stages of dance and performance. According to Peluffo Linari, this phrase began acquiring significance at the end of the 1960s, when the police would kneel down to throw fragmentation bombs against protesters, and the protesters would correspondingly resist. During the early 1960s, the dancer Graciela Figueroa went out into the street to make corporeal representations-performances-alluding to these forms of urban violence. Peluffo Linari also associates the phrase to the "thematic ambiances" or "actions with theme" created by artist and performer Teresa Vila during the late 1960s and early 1970s, in which she divided the audience into groups, each of which performed different actions that culminated in the creation of a simulated atomic bombing, including written texts about war. He also points out that anyone who was in their twenties at that time had to "place the body." This experience was not only linked to political militancy but also inscribed within a wider field of reference. It related, for example, to conversations about free love and to the "excursions with the goal of gaining independence from family tutelage," particularly for women. These excursions, organized at the high-school level, were connected 
to education mechanisms coordinated by the Frente de Estudiantes Revolucionarios (FER; Front of Revolutionary Students). They were journeys referred to as "going to make love in Atlantida" - a beach on the Uruguay coast. These actions signaled, according to Peluffo Linari, "un reposicionamiento de lo corporal en el nivel de las conductas que el sistema no permitía" (a repositioning of the body at the level of behavior that the system did not permit). ${ }^{14}$ With these actions, the body acquired a new centrality in the artistic languages of the 1960s and 1970s. Dancers such as Inge Bayerthal, Norma Quijano, Graciela Figueroa, and Teresa Trujillo were central to what was called "transversalización de las disciplinas" (a transversalization of disciplines), a form of research around the body that linked dance, music, and nontraditional stage elements. ${ }^{15}$

In these emergent "corporealities," the space of experimental art was linked to a political space. Printmaking practices that developed during the years of the dictatorship are a case in point. Created in 1953, the Club de Grabado (Print club), which counted Romero as a member, aimed to demystify the sense of an "original" artwork by proposing popular access to images. ${ }^{16}$ In opposition to various aspects of cultural control-the guidelines and policies of the dictatorship - the club created slogans and boycotts. Their widely circulated monthly prints referred to the Vietnam War, the revolution, and murdered student leaders (such as Heber Nieto, assassinated during a protest). During the years of the dictatorship, when they were unable to perform their educational mission in schools or within the sphere of their trade union-that is, when their activity was limited to teaching inside the studio, where they produced monthly prints and almanacs- their production, reproduction, and distribution of images became expressions of militancy. ${ }^{17}$ During those years, writes Peluffo Linari, the club ran as a

micro-espacio de intercambio y producción de ideas para un círculo de personas interesadas en la comunicación visual, reunidas por un pacto elíptico de confianza y complicidad ... capaz de sostenerse como tal a través de un sentimiento de pertenencia y resistencia silenciosamente compartido.

[micro-space of exchange and production of ideas for a circle of people interested in visual communication, coming together through an elliptical agreement of trust and complicity ... able to sustain itself via a silently shared feeling of belonging and resistance. $]^{18}$

At that moment, certain intellectuals joined the club, leading courses or participating in print production-becoming part of this "deliberative enclave" linked to other microsocial constructions of subjectivities operating at the margins and against the system. ${ }^{19}$ Such a network can be traced among the Club de Grabado, the Cinemateca, and the Teatro Circular de Montevideo. 
The Club de Grabado elaborated strategies of visual communication aimed at eluding the censorship of the military dictatorship. Thus the prints made there often refer to bindings, injuries, or adhesive tape. ${ }^{20}$ Nelbia Romero and Ana Tiscornia's 1983 prints introduce tears, covered faces, and images that refer to laceration, identity, and violence. These features, in addition to the color contrast characteristic of the poster style, aimed to generate allegorical languages. As part of this repertory, the concept of "huella" (footprint) was also important, as it linked the body to the idea of image transfer. ${ }^{21}$ The group support and conversation around technical devices functioned as channels for poetic and political communication that was sustained throughout the years of the dictatorship.

On experience of the Club de Grabado from within, Romero writes:

La resistencia al oscurantismo dictatorial puso a prueba nuestras convicciones ideológicas personales y de grupo, amalgamando diferencias individuales en pos de salvaguardar la existencia y sustentabilidad del proyecto cultural. Este hecho coyuntural fortaleció al grupo humano que, desde la multiplicidad de funciones y compromisos internos, definió estrategias de sobrevivencia.

[The resistance to the obscurantism of the dictatorship tested our personal and collective ideological convictions, amalgamating individual differences in a pursuit to protect the existence and sustainability of the cultural project. These circumstances strengthened the human group that, from a multiplicity of functions and internal commitments, defined survival strategies. ${ }^{22}$

The idea of the body's print is visible in the 1981 series Ocultamientos (Concealments), which starts as a self-portrait in the shape of a mask that is then manipulated with stitching, tears, casts, collages, and glazing on translucent paper or bubble wrap. The image is generated from a photograph of Romero's ink-covered face, which she then used to make an impression on paper. ${ }^{23}$ This use of the body as the foundation of an image links the discussion of the corporeal footprint to stories of torture and the disappeared. It was a way, Peluffo Linari points out, of representing the presence-absence tensions that crossed the social plot. ${ }^{24}$ Printed corporeality, then, stretched the limits of print such that the self-portrait under the conditions of repression could become a confrontation.

\section{Resistance}

All of these materials were part of Montevideo's cultural scene in 1983, two years before the end of the dictatorship, when there were prisoners in the jails, when normalcy was marked by fear, censorship, oppression, and control. According to testimonies, Romero's Sal-si-puedes was felt as an indirect reference to repression: a bridge between the violence organized by 
the shaping discourse of national history and the discourse that dominated the present but didn't yet have the definitive narratives to give it shape.

Artist Ana Tiscornia writes:

Estuvo claro para todo el mundo que esta instalación hablaba de la situación por la que atravesábamos, y eso incidió también en lo bien recibido que fue el trabajo. Era difícil en ese tiempo encontrar la metáfora capaz de denunciar la dictadura y pasar la censura. Nelbia tuvo la virtud de establecer un paralelo históricamente tan distanciado como para no despertar sospechas. Ella estaba genuinamente interesada en el tema de los charrúas y su eliminación de la historia, no sólo en un episodio como Salsipuedes y la liquidación de una enorme cantidad de indígenas, sino también en la negación de su presencia en el tejido cultural de nuestro país.

[It was clear to everyone that this installation spoke of the situation we were going through, and that had a lot to do with why the work was so well received. It was difficult during that time to find the metaphor that was able to denounce the dictatorship and bypass censorship. Nelbia had the virtue of establishing a parallel that was historically distanced enough to avoid raising suspicions. She was genuinely interested in the topic of the Charrúas and their elimination from history, not only through an episode such as Salsipuedes and the extermination of an enormous number of indigenous people but also in the negation of their presence within the cultural fabric of our country. ${ }^{25}$

In a later text she confirms this perception:

Todo el mundo la leyó en tiempo presente como una manera de hacer un enunciado contra la dictadura en clave histórica.

[Everyone read it in the present as a way of speaking against the dictatorship in historical code. ${ }^{26}$

Peluffo Linari relates this interpretation to a series of examples in which certain works, he argues, were understood in a double register of the literal and the metaphorical:

Desde la música "popular" ("Los que iban cantando"), el teatro ("Los fusiles de la patria vieja," por ejemplo), desde las performances e instalaciones se hablaba siempre en doble registro: por un lado se aludía a hechos (generalmente históricos) o a vivencias cotidianas, pero por otro esos hechos y esas vivencias estaban deliberadamente hablando de la situación en dictadura (y esto no era del todo explícito: el público buscaba la vuelta para encontrar ese significado). Todos hablábamos en "doble registro" incluso por teléfono.

[Through "popular" music ("Those Who Were Singing"), theater ("The Guns of the Old Country," for example), through performances and installations, speaking always happened in a double register: on the one hand alluding to facts (generally historical) or to everyday life, and on the other those facts and those quotidian experiences were deliberately speaking of a circumstance within the dictatorship 
(and this was not fully explicit: the audience took the extra step of finding this meaning). We all spoke in this "double register," even over the phone.]

En primer lugar, no vas a encontrar ninguna publicación de la época que diga eso (iiies obvio!!!). Ese pacto social era un secreto a voces, pero la censura y la autocensura no dormían. Yo recuerdo que en el proceso de trabajo Nelbia pensó en el espectáculo de "danza" dentro de la carpa como una forma de amortiguar el efecto de alusión directa que podrían tener los maniquíes deshechos y las jaulas de madera. Aún así muchos pensamos que la exposición podría llegar a ser censurada porque era lo más arriesgado que se había visto hasta el momento. En segundo lugar, ese hablar en doble registro permitía que la elección del hecho o vivencia tomado como "tema" o punto de referencia fuera de libre elección del artista. Y en este sentido, la elección del exterminio charrúa era algo que estaba-puede decirse-en la biografía de Nelbia, porque ella era nacida en Durazno y allí quedan todavía muchos legados guaraníes y charrúas. Hay otras instalaciones de ella posteriores a Sal-si-puedes que tocan ese asunto, porque era obsesivo en su trabajo.... Ella juntó en un mismo acto dos "rabias" personales: la del exterminio indígena y la de la desaparición de sus propios compañeros de militancia.

[To begin with, you won't find a publication of that time that says this (it's obvious!!!). That social pact was a resounding secret, but censorship and selfcensorship didn't sleep. I remember that in her work process Nelbia thought of the "dance" performance inside of the tent as a way of softening the direct allusion that the broken mannequins and the wooden crates could make. And still many of us thought that the exhibit could have been censored because it was the most audacious thing that had been seen until that moment. Second, speaking in that double register allowed the artist to choose freely the fact or everyday life experience to be used as "theme." In this way, the choice of the Charrúa extermination was something that was-one could say-part of Nelbia's biography, as she had been born in Durazno, where there are still many Guaraní and Charrúa legacies. She has other installations that followed Sal-si-puedes that touch upon this, because it was an obsession in her work.... She brought together in one act two personal "rages": one over the indigenous extermination and the other over the disappearance of her own fellow activists. ${ }^{27}$

However, no texts contemporary with the installation exist in which Romero and the creative team state that the piece referred to the dictatorship. Nor is there documentation proving that this was how the piece was interpreted at the time. But the critical reviews move in this direction. ${ }^{28}$ Alicia Haber, who wrote two reviews of the installation, highlights its experimental character, its interdisciplinary elements, its "multi-media" approach, and the artist's intention to investigate "los males de la colonia y sus consecuencias culturales" (the evils of the colony and its cultural consequences) since the massacre of the Charrúa people. She describes the installation's walkthrough up to the arrival at the "gran escenografía constituida por maniquíes desarticulados y yacentes, en posturas que concitan la idea de masacre y de sangre.... Todo culmina en una serie de elementos de madera que pueden inducir a pensar 
en ataúdes o celdas" (the great scenography made up of unarticulated, reclining mannequins, in poses that incite the idea of massacre and blood.... It culminates in a series of wooden elements that can suggest caskets or cells) ${ }^{29}$ "Massacre," "caskets," "cells": the words may refer to the Uruguayan context of the dictatorship, but they also apply to the theme the artist takes on in her texts. In 1992, Luis Camnitzer published what was probably the first written interpretation that detached Sal-si-puedes from the eighteenth-century massacre: "In Romero's work, made and performed by a collective in 1983, the massacre at Sal-si-puedes becomes a pointed metaphor for the violence reenacted in the 1970 s and 1980s by the Uruguayan dictatorship." 30

When I asked art critic Olga Larnaudie about the historicity of this relationship, her response was forceful: "Por supuesto que no es una interpretación posterior. ... No es un argumento ‘impreso' el que te podría dar, estábamos aquí al lado de Nelbia y cada uno a su manera hacía lo suyo, cuando se pudo" (It certainly isn't a later interpretation.... It's not an argument that I can give you 'in print,' we were here, next to Nelbia, and each one of us, in our own way, did what we could, when we could). She refers to a network of cultural spaces in which shared oppositional practices were carried out, practices that offered political texture to "aquel Uruguay de la resistencia en que logramos vivir y meternos por muchos lados, en el Club, en (la) Cinemateca, en el Teatro Circular" (the Uruguay of the resistance in which we managed to live and to enter through many fronts, through the Club, the Cinemateca, and the Teatro Circular).$^{31}$

Although the texts that accompanied the installation don't introduce a relationship to the present, they include visual and written references (broken mannequins, ropes, crates that resemble caskets or cells, and texts that invoke a massacre) that allowed them to be linked to the dictatorship that at that moment dominated social and political life in Uruguay. Those who remember agree on this. Peluffo Linari points out that the broken mannequins and the wooden cages were a "direct allusion": so direct that many thought the exhibit could be censored as it was "lo más arriesgado que se había visto hasta el momento" (the most audacious thing that had been seen until that moment). ${ }^{32}$ What was produced by the interpretation of the installation was a community of understanding, a microcommunity that interpreted the work in relation to what was taking place in Uruguay at that moment, what was experienced in the prisons, specifically in the Libertad prison, fifty kilometers outside of Montevideo. The dissident power of a work such as this, its ability to invoke an experience without naming it, without introducing slogans or photographs, is, unquestionably, ambiguous, and difficult to demonstrate. Still, what I propose here-a hypothesis I have developed in earlier texts-is that certain works created during the dictatorship can be understood as resistant visualities. ${ }^{33}$ Not explicit, yet resistant. Such 
forms of resistance are articulated through interpretive agreements woven into a specific social and cultural scene that allow for the consideration of past histories or general themes in relation to contemporary circumstances. The resistant visuality is a denunciation that is never represented, yet audiences see and interpret it as if it were real. This "representation" from a place of no representation should be understood, of course, in neither a literal nor a judicial sense. What testimonies agree upon is that this is how it was felt (that is, as resistance). Although it is true that because Romero's installation coincided with Rivera's anniversary there were military personnel positioned at its stairs for as long as it remained open, these guards were apparently unaware of the meaning of Sal-si-puedes. ${ }^{34}$ The censors were not, from that perspective, thoroughly efficient.

According to Néstor García Canclini, images, the imagined, and the imaginary are effects of social practices that transcend the logic of their creators and settle within complex social interactions. ${ }^{35}$ In that sense, the community of understanding that I hypothesize is linked to a combination of complex materials, among which exist the facts of the image (references to the massacre, the prison) but also the cultural formation within which Romero's practices were situated. The fact that she was a member of both the Communist Party and the Club de Grabado; that she was part of circles persecuted by the dictatorship and participated in activities that aimed to maintain a cultural scene within a context that was headed toward the dissolution of critical thought; and that this installation took place in the Galería del Notariado, directed by Nancy Bacelo, founding poet of the Feria de Libro y Grabados (Book and print fair) in 1959-all of these facts make a convincing argument that Sal-si-puedes not only meant to denounce the massacre upon which the republic was founded but also to denounce what was happening at that time in Uruguay. ${ }^{36}$ On this point, those who remember agree.

Is it possible, on these terms, to consider Sal-si-puedes as work of resistance? No work is essentially any one thing (good, bad, political, poetic, symbolic, or resistant). What a piece is is not established through individual and specific conditions that allow for a definitive categorization-not even within the rubric of "a work of art"-but instead an artwork is defined through the ways in which it is perceived. It is good, bad, political, poetic, or resistant as a result of the reactions it produces in its audiences, whether or not these are specific to the world of art. Thus I agree with Jean-Marie Schaeffer when he notes the substantiating and objectifying impulse that characterizes Western culture. Other human communities, he points out, "piensan lo real en términos de procesos, de transformaciones, de interdependencias y de interacciones en vez de hacerlo en términos de objetos" (think of the real in terms of processes, of transformations, of interdependencies and of interactions, instead of in terms of objects). ${ }^{37}$ Thus, when I 
understand a work as "resistant," I don't suggest that such a condition may be ratified in any substantial way. It is the interpretations of the work that make of it an example of resistance art. What is it, then, that qualifies a piece to be recognized as resistant?

As Jocelyn A. Hollander and Rachel L. Einwohner write, the term "resistance" is used so widely (from anthropology to cultural studies, gender studies, and, in our case, art history) that it is unclear that everyone is referring to the same thing. ${ }^{38}$ Some authors consider everyday practices that oppose oppressive power through low-profile strategies to be forms of resistance, forms that are difficult to identify and that therefore protect their users from the oppressor. ${ }^{39}$ To others the term can only be applied to visible, collective actions that work toward social change, not to forms of resistance in everyday life. ${ }^{40}$ Differences in the identification of resistance acts depend on the recognition of such actions by those who formulate them. For James Scott it is enough that these actions be recognized as resistant by culturally conscious observers; for Jeffrey Rubin the term must be reserved for those situations in which all actors are equally conscious. Intention, or the awareness of those who carry out the act of resistance, is also a determining factor. It is evident, as Scott points out, that when public acts are too dangerous, forms of resistance may be produced in private practices. ${ }^{41}$ For these forms of resistance to be efficient cultural codes must be shared between those who formulate and those who decode them. According to Hollander and Einwohner, visibility, recognition, and intention are the parameters by which a homogeneous notion of resistance is constituted. Yet, these features aren't always complete or clearly identifiable. Depending on the ways in which forms of resistance are manifested, Hollander and Einwohner propose typologies that differentiate open resistance from concealed forms. Sal-si-puedes should be placed among the latter. The artist's testimony and those of the installation's audience express their understanding of the work as resistant in as much as it represented the object of resistance as an expression contrary to repressive power. Resistance, then, being socially constructed, depends on the acknowledgment of the audience.

In any case, the military officials in power did not realize the resistant character of the work, a fact that demonstrates the way in which resistance can coexist with forms of domination. In this sense, notions of ambiguity, complicity, and assimilation intervene to account for the changing relationships between forms of resistance and their neutralization. Shown in a building open to the public, Sal-si-puedes adjusted and assimilated itself to, in a sense, the conditions of representation permitted within the dictatorship. At the same time, for its producers and the intellectual community that saw it, the work had a clear sense of denunciation in its reference to contemporary violence. 
It is evident that if we link the notion of resistance to one of social change, Romero's installation did not have the power to produce the latter. In fact, no work of art could have the power to end a dictatorship. Civilian opposition in Uruguay was primarily articulated through human rights organizations, in a climate of mobilization that increased with the economic and military failures of Latin American dictatorships (for example Argentina's, resulting in the Malvinas/Falklands War). Yet, the failures of these dictatorships were made possible not only through acts of undeniable force but also thanks to the denouncements made through the cultural practices of resistance. The idea that runs through the quoted sources is that in the face of a power aiming to eliminate critical thought among the populace (and to this end tortured and murdered militants and intellectuals, burned books, and obliterated murals), the expression of veiled and embedded meanings contrary to this power was a form of resistance. This resistance has been made visible not only by the actors in the cultural scene under the dictatorship but also by those who write in the present about the culture of those years. Postdictatorship societies were affected by conflicts that laid out hierarchies of resistance, legitimate or correct forms of resistance. These hierarchical positions involve ethical matters that crossed the debates about exile and insilio (resident exile). Is it possible to classify works as ethical or unethical depending on their declared stance against the dictatorship? Must we discard the interpretive pacts articulated during those years that come to us through coinciding testimonies? The application of a binary ethics runs the risk of replicating, in a sense, the binary ethics of all authoritarianism.

The memories, and the descriptions these afford of the ways certain works were perceived, provide materials for understanding dissident subjectivities and allow us to approximate the texture of different forms of cultural resistance. Sal-si-puedes was, in a sense, a precarious monument around which various actors plotted secret meanings that allowed them to identify with one another, tracing networks of solidarity founded on interpretation. They felt they fractured the limits of what it was possible to say through a piece that was, in a way, excessive, in that it involved "it all," both the past and the present. The resulting conquest of these reserved territories of meaning was-why not say it this way-a symbolic form of victory. Recognizing these dissident subjectivities doesn't aim to reconstruct a heroic history of the past or to heroize those who take it on in the present. It aims to capture and make visible the articulations of meaning that cannot be eliminated from a perspective that would dilute them through its exclusionary classification of legitimate or illegitimate forms of resistance.

-Translated by Martha Herrera-Lasso

Archives, Performance, and Resistance in Uruguayan Art Under Dictatorship 
I would like to thank Mariela Blanco, Olga Larnaudie, Gabriel Peluffo Linari, and Ana Tiscornia for their collaboration in the research for this essay.

1. A. Rico, "Del orden político democrático al orden policial del Estado," Brecha 6 (2003): II-III, "Separata 1972. El año de la Furia"; Graciela Sapriza, "Memorias de mujeres en el relato de la dictadura (Uruguay, 1973-85). Violencia/carcel/ exilio," in "Violenza, conflitti e migrazioni in America latina," special issue, Deportate, Esuli e Profughe. Rivista telematica di studi sulla memoria femminile. 11 (July, 2009): 64-80.

2. Nelbia Romero, interview with the author, Montevideo, 6 July 2014.

3. Photographs by Diana Mines, Uruguayan photographer and feminist who in 1988 organized the collective exhibit of women photographers Campo Minado in Montevideo.

4. Photographs by Carlos Etchegoyen, psychoanalyst and photographer, who was part of the Sal-si-puedes creative team. The performance was created by dancers from the group Babinka, of which Romero was a member, a group run as a cooperative with no internal hierarchies; Elisa Perez, "Itinerarios de la danza independiente durante la última dictadura en Uruguay" (lecture given at Aproximaciones al estudio de la danza en el Uruguay: miradas interdisciplinarias, V Jornadas de Investigación - IV Jornadas de Extensión · III Encuentro de Egresados y Maestrandos realizadas en FHCE-Udelar October 9, 10, and 11, 2013), http:/ / estudiosdeladanzaenuruguay.blogspot.com.ar/2013/10/elisa-pereztexto-completo.html. Romero later studied with Norma Quijano, director of dance and corporeal expression at the theaters El Galpón and El Circular, and with dancer and choreographer Cristina Martínez.

5. Fernando Condon is an Uruguayan musician, composer, and orchestra conductor who has made music for film and theater since 1981.

6. Nelbia Romero (Coord.), Sal-si-puedes, Montevideo: Galería del Notariado, 26 October-13 November 1983.

7. Juan Antonio Lavalleja (1930), quoted in Renzo Pi Hugarte, "Carta de Lavalleja a Rivera, 24 de febrero de 1830," in El Uruguay indígena (Montevideo, 1969).

8. Darío Arce Asenjo, "Nuevos datos sobre el destino de Tacuavé y la hija de Guyunusa," in Sonnia Romero Gorski, ed., Anuario de Antropología Social y Cultural en Uruguay (Montevideo, 2007), 51-71.

9. Ibid., 63.

10. Translator's note: Criollos were members of a social class in the Spanish colonies composed of locally born people of European descent. Quotation from Julio María Sanguinetti, "El charruismo," El País, 19 April 2009, http://historico. elpais.com.uy/09/04/19/predit_411886.asp.

11. Gonzalo Abella, "Salsipuedes es la primera acción del terrorismo de Estado en Uruguay,” Mañana de Radio, 7 April 2014, http://www.radio36.com.uy/ entrevistas/2014/04/09/abella.html.

12. Mark Godfrey, “The Artist as Historian,” October 120 (Spring 2007): 140-72.

13. Romero, interview.

14. Gabriel Peluffo Linari, interview with the author, Montevideo, 3 July 2014.

15. Ibid.

16. Gabriel Peluffo Linari, "1953-1976: Club de Grabado y la "cultura independiente,"” in Club de Grabado de Montevideo, 1953-1993 (Montevideo, 2012). 
17. Peluffo Linari, Club, 59.

18. Ibid., 71.

19. Olga Larnaudie, Gabriel Peluffo Linari, Ana Tiscornia, and Alfredo Torres are incorporated; ibid., 73, 75; Felix Guattari and Suely Rolnik, Micropolítica. Cartografías del deseo (Buenos Aires, 2012).

20. Peluffo Linari, Club, 77.

21. Translator's note: In Spanish the word huella can be translated as "footprint," "print," or "trace," but not as a "print" in the sense of a printed image (which in Spanish is grabado). Thus, in Spanish the analogy the author describes in this section does not rely on the double meaning of the word print as it does in the English translation.

22. Nelbia Romero, quoted in Olga Larnaudie, Nelbia Romero (Montevideo, 2012), 103.

23. This experience is described by Peluffo Linari, interview. Unfortunately none of these prints have been preserved.

24. Ibid.

25. Ana Tiscornia, e-mail correspondence with the author, 30 September 2014.

26. Ana Tiscornia, e-mail correspondence with the author, 4 June 2015.

27. Translator's note: Los Que Iban Cantando (Those who went along singing) was a Uruguayan band of the 1970s and 1980s made up of members of the cultural resistance. Translator's note: Los Fusiles de la Patria Vieja (The Old Nation's Rifles), directed by Omar Grasso, was an adaptation of Bertolt Brecht's Señora Carrar's Rifles produced at the Teatro Circular in Montevideo in 1971. Peluffo Linari, e-mail correspondence with the author, 2 August 2015.

28. Four reviews were written during the exhibition, two published by the weekly Aqui were not signed, and two published by the newspaper El Pais were written by Alicia Haber.

29. Alicia Haber, “'Sal-si-puedes' en el Notariado," El País, 21 November 1983.

30. Luis Camnitzer, "Recent Latin American Art," Art Journal 51, no. 4 (1992): 6.

31. Olga Larnaudie, e-mail correspondence with the author, August 4, 2015.

32. Peluffo Linari, e-mail correspondence with the author, 2 August 2015.

33. Andrea Giunta, "Pintura en los 70: inventario y realidad," in Centro Argentino de Investigadores de Artes, Arte y Poder: 5 as. Jornadas de Teoría e Historia de las Artes, Facultad de Filosofía y Letras (UBA) del 8 al 11 de septiembre de 1993 (Buenos Aires, 1993), 215-24; Andrea Giunta, "Juan Pablo Renzi, problemas del realismo," Punto de Vista, Año 25, no. 74 (2002): 43-47.

34. Romero, interview.

35. Néstor García Canclini, "El poder de las imágenes. Diez preguntas sobre su distribución internacional," Estudios Visuales no. 4 (2007), http://estudiosvisuales. net/revista/pdf/num4/canclini-4.pdf.

36. Peluffo Linari, e-mail correspondence.

37. Jean-Marie Schaeffer, "Objets esthétiques?," L'Homme, Revue francaise d'anthropologie no. 170 (2004): 25-46. Published in Spanish as Jean-Marie Schaeffer, Arte, objetos, ficción, cuerpo. Cuatro ensayos sobre estética (Buenos Aires, 2012), 49-77, 54.

38. Jocelyn A. Hollander and Rachel L. Einwohner, "Conceptualizing Resistance," Sociological Forum 19, no. 4 (2004): 533-54.

39. James C. Scott, Weapons of the Weak: Everyday Forms of Peasant Resistance (New Haven, 1985).

40. Jeffrey W. Rubin, "Defining Resistance: Contested Interpretations of Everyday Acts," Studies in Law, Politics and Society 15 (1996): 237-60, 241.

41. Scott, Weapons, 290. 